\title{
Pax8, a murine paired box gene expressed in the developing excretory
}

\section{system and thyroid gland}

\author{
DIMITRIJ PLACHOV ${ }^{1}$, KAMAL CHOWDHURY ${ }^{1}$, CLAUDIA WALTHER ${ }^{1}$, DOMINIQUE SIMON ${ }^{2}$, \\ JEAN-LOUIS GUENET ${ }^{2}$ and PETER GRUSS ${ }^{1}$ \\ ${ }^{1}$ Max Planck Institute for Biophysical Chemistry, Department of Molecular Cell Biology, 3400 Göttingen, FRG \\ ${ }^{2}$ Unitre de Genetique de Mammiferes, Institut Pasteur, 25 rue de Dr Roux, Paris 75724 Cedex 15, France
}

\section{Summary}

Several mouse genes designated 'Pax genes' contain a highly conserved DNA sequence homologous to the paired box of Drosophila. Here we describe the isolation of $P a x 8$, a novel paired box containing clone from an 8.5 day p.c. mouse embryo cDNA library. An open reading frame of 457 amino acids (aa) contains the 128 a paired domain near the amino terminus. Another conserved region present in some other paired box genes, the octapeptide Tyr-Ser-Me-Asn-Gly-Leu-Leu-Gly, is located 43 aa $C$-terminal to the paired domain. Using an interspecies backcross system, we have mapped the $\operatorname{Pax} 8$ gene within the proximal portion of mouse chromosome 2 in a close linkage to the surf locus. Several developmental mutations are located in this region. In situ hybridization was used to determine the pattern of Pax8 expression during mouse embryogenesis. $\operatorname{Pax} 8$ is expressed transiently between 11.5 and 12.5 days of gestation along the rostrocaudal axis extending from the myelencephalon throughout the length of the neural tube, predominantly in two parallel regions on either side of the basal plate. We also detected $P a x 8$ expression in the developing thyroid gland beginning at 10.5 days of gestation, during the thyroid evagination. In the mesonephros and metanephros the expression of Pax8 was localized to the mesenchymal condensations, which are induced by the nephric duct and ureter, respectively. These condensations develop to functional units, the nephrons, of the kidney. These data are consistent with a role for $\operatorname{Pax} 8$ in the induction of kidney epithelium. The embryonic expression pattern of $P a x 8$ is compared with that of $P a x 2$, another recently described paired box gene expressed in the developing excretory system.

Key words: paired box, Pax cDNA, mouse chromosome 2, kidney development, thyroid development, mouse embryogenesis.

\section{Introduction}

The molecular mechanisms governing mammalian development are poorly understood. The investigation of these mechanisms is hampered mainly due to the lack of mutants in which the genes involved in the developmental control are affected. However, a number of developmental mutants have been identified in Drosophila (Lewis, 1978; Nüsslein-Volhard and Wieschaus, 1980), facilitating the isolation of the corresponding genes (for review see Akam, 1987). A complex network of molecular interactions leading to the establishment of segmentation and segment identity of the Drosophila embryo is being revealed (for review see Scott and Carroll, 1987; Ingham, 1988).

One approach used to identify the molecules involved in mammalian development takes advantage of the fact that certain protein domains such as the homeobox, a common motif among the Drosophila developmental genes, are strongly conserved in evolution (McGinnis et al. 1984). Thus, numerous murine homeobox-containing genes have been identified by screening with Drosophila homeobox probes and the expression of these genes in the developing embryo has been studied (for review see Holland and Hogan, 1988).

Another conserved domain of 128 amino acids, the paired box, was identified in the Drosophila segmentation genes paired (Kilchherr et al. 1986; Frigerio et al. 1986), gooseberry-distal and gooseberry-proximal (Baumgartner et al. 1987; Côté et al. 1987) suggesting a functional role for this domain in the process of Drosophila segmentation (Bopp et al. 1986). Subsequently, two additional Drosophila paired box genes of unknown function, Pox meso and Pox neuro, were cloned (Bopp et al. 1989). The paired box domain is also conserved in the evolution of fly, mouse and man (Dressler et al. 1988; Burri et al. 1989). Because various segmented structures, such as somites and mesonephric tubules, appear during the mouse development (Hogan et al. 1985), an intriguing possibility is that paired box genes are also involved in the process of mammalian segmentation. Indeed, $\operatorname{Pax} 1$, a murine paired box gene, 
is expressed in a segmented manner in the intervertebral disk anlagen along the entire vertebral column (Deutsch et al. 1988). Furthermore, a point mutation in the highly conserved region of the paired box of $\operatorname{Pax} 1$ is associated with the undulated mutant, characterized by malformations in the vertebral column (Balling et al. 1988). Another recently described murine paired box gene, $P a x 2$, is expressed in restricted regions along the entire developing spinal cord as well as in the mesonephros and metanephros (Dressler et al. 1990; Nornes et al. 1990). The mesonephric nephrons constitute a segmented structure. Hence, the expression of $P a x 2$ in this tissue supports a possible role for this gene in the segmentation of the mouse embryo.

Several paired box sequences have been detected in the mouse genome by hybridization (Dressler et al. 1988). As a first step to understanding the underlying mechanisms by which members of the Pax gene family function, we have sought to identify additional paired box genes of the mouse. In this report we describe the isolation and sequence of a novel paired box gene, Pax8. We show that Pax 8 is closely linked to the surfeit (surf) gene cluster near the centromere of chromosome 2. Using in situ hybridization, we demonstrate that Pax8 is expressed in restricted regions of the developing mouse embryo. The expression pattern is compared with that of the $\operatorname{Pax} 2$ gene, whose paired domain shows an extensive homology to the paired domain of Pax8. Comparison of the spatial pattern of expression of both genes in the developing metanephros is especially instructive. The morphogenesis of the metanephros results from mutual inductive interactions between the ingrowing ureteric bud and the metanephrogenic mesenchyme. During this process the branching ureter induces in the mesenchyme the cellular condensations that develop shortly thereafter to the S-shaped bodies, the precursors of the nephrons (for review see Potter, 1972; Saxen, 1987). We report here that $\operatorname{Pax} 8$ is expressed predominantly in the induced tissues, mesenchymal condensations and the S-shaped bodies. Pax 2 is expressed in the ureter, condensations, and S-shaped bodies. The results suggest a function for both genes in the inductive process of kidney development.

\section{Materials and methods}

\section{cDNA library screening}

Initially, the cDNA clone 960 was isolated from an 8.5 days p.c. embryonic C57BL/ 6 mouse $\lambda$ gt $10 \mathrm{cDNA}$ library (Fahrner et al. 1987) in a low-stringency screen (hybridization in $7 \times$ SSC at $60^{\circ} \mathrm{C}$ with a subsequent washing in $2 \times \mathrm{SSC} / 0.2 \% \mathrm{SDS}$ at $42^{\circ} \mathrm{C}$ ) using a mixture of $\operatorname{Pax} 1, \operatorname{Pax} 2$ and $\operatorname{Pax} 3$ paired box probes (Deutsch, unpublished). DNA sequencing revealed that this clone had part of a novel paired box. A $112 \mathrm{bp}$ fragment containing the partial paired box sequence of $c 960$ was labeled by random priming (Feinberg and Vogelstein, 1983 ) and used to screen $6 \times 10^{8}$ clones of the same cDNA library under high-stringency conditions (hybridization in $500 \mathrm{~mm} \mathrm{NaPi}, \mathrm{pH} 7.2 / 7 \% \mathrm{SDS} / 1 \mathrm{~mm}$ EDTA at $65^{\circ} \mathrm{C}$; washing several times in $40 \mathrm{~mm} \mathrm{NaPi}, \mathrm{pH} 7.2 / 1 \% \mathrm{SDS}$ at $65^{\circ} \mathrm{C}$ ).

\section{DNA sequencing}

The overlapping restriction fragments of the Pax 8 cDNAs were cloned into the plasmid vector Bluescript KS (Stratagene) and sequenced from both strands by the dideoxy method (Sanger et al. 1977) using commercial sequencing kits (Sequenase, US Biochemicals; T7, Pharmacia).

\section{Embryos and tissues}

Embryos for RNA isolation and in situ analysis were obtained from natural matings of female NMRI mice. The day of the vaginal plug was designated as day 0.5 p.c. Tissues were isolated from adult NMRI mice.

\section{RNA isolation and Northern blot analysis}

Total RNA was isolated by homogenizing tissues and embryos in guanidinium thiocyanate (Chirgwin et al. 1979) followed by centrifugation through a $5.7 \mathrm{M} \mathrm{CsCl}, 25 \mathrm{~mm}$ sodium acetate pH 5.0 gradient in a Beckman SW40 rotor spun at 30000 revs$\mathrm{min}^{-1}$ for $24 \mathrm{~h}$. Poly (A) ${ }^{+}$RNA was isolated using oligo(dT)cellulose columns. $5 \mu \mathrm{g}$ of the respective RNA samples were electrophoresed through $1 \%$ agarose gels containing 3.7\% formaldehyde and Mops buffer (20 mm morpholine propane sulfonic acid, $50 \mathrm{~mm}$ sodium-acetate, $10 \mathrm{~mm}$ EDTA, $\mathrm{pH} 7.0$ ). RNA was blotted onto nylon membranes (Hybond-N) with $10 \times \mathrm{SSC}$ and hybridized overnight in $50 \%$ formamide, $5 \times \mathrm{SSC}$ at $42^{\circ} \mathrm{C}$. The membranes were then washed twice in $0.1 \times \mathrm{SSC}, 1 \% \mathrm{SDS}$ at $65^{\circ} \mathrm{C}$ for $15 \mathrm{~min}$ each.

\section{In situ hybridization}

The cDNA fragments chosen as templates for in vitro transcription were cloned into the Bluescript KS vector (Stratagene) and the resulting plasmids were linearized with restriction endonuclease. These templates were transcribed using T3 or T7 RNA polymerase (Promega Biotech), ${ }^{35} \mathrm{~S}$ UTP and ${ }^{35}$ S-CTP (each approximately $100 \mu \mathrm{Ci}$ ) and then degraded by DNAse digestion. RNA probes were precipitated with $10 \%$ trichloracetic acid, collected on nitrocellulose filters (Millipore), eluted by brief boiling, and incubating at $65^{\circ} \mathrm{C}$ in $20 \mathrm{~mm}$ EDTA $\mathrm{pH} 8 / 0.1 \%$ SDS. After ethanol precipitation, the probes were partially degraded in $0.2 \mathrm{~N}$ $\mathrm{NaOH}$ on ice for $30 \mathrm{~min}$, neutralized with $1 \mathrm{~m}$ acetic acid and ethanol precipitated. The probes for in situ hybridization were resuspended at $5 \times 10^{4} \mathrm{cts} \mathrm{min}^{-1} \mathrm{ml}^{-1}$ in hybridization buffer (50\% formamide; $2 \times \mathrm{SSC} ; 10 \mathrm{~mm}$ Tris, $\mathrm{pH} 7.5 ; 10 \mathrm{~mm} \mathrm{NaPi}$, pH 6.8; $5 \mathrm{~mm}$ EDTA; $10 \%$ dextran sulfate; $10 \mathrm{~mm}$ DDT; $10 \mathrm{~mm} \beta$-mercaptoethanol; $1 \mathrm{~mm}$ ADP- $\beta$-S; $0.1 \mathrm{~mm}$ UTP; $10 \mu \mathrm{m} \mathrm{S}$-ATP; $150 \mu \mathrm{g} \mathrm{ml}^{-1}$ salmon sperm DNA; $150 \mu \mathrm{g} \mathrm{ml}^{-1}$ yeast $t$-RNA).

Preparation of sections and in situ hybridization was done as described by Hogan et al. (1986) with modifications. Embryos were frozen in isopentane on dry ice and $8 \mu \mathrm{m}$ cryosections were cut at $-19^{\circ} \mathrm{C}$. Sections were dried at $55^{\circ} \mathrm{C}$, fixed in $4 \%$ freshly dissolved paraformaldehyde, dehydrated in graded ethanol series, air dried and stored at $-20^{\circ} \mathrm{C}$ until use. Prior to hybridization, slides were treated successively in water, $1 \mathrm{~min} ; 2 \times \mathrm{SSC}, 30 \mathrm{~min}$ at $70^{\circ} \mathrm{C} ; \mathrm{H}_{2} \mathrm{O}, 1 \mathrm{~min}$; $0.125 \mathrm{mg} \mathrm{ml}^{-1}$ pronase, $10 \mathrm{~min}$ at room temperature; $0.2 \%$ glycine, $30 \mathrm{~s}$; PBS, $1 \mathrm{~min}$; $4 \%$ paraformaldehyde, $20 \mathrm{~min}$; PBS, $1 \mathrm{~min} ; 0.1 \mathrm{~m}$ triethanolamine with $1 / 400$ volume acetic acid, $10 \mathrm{~min}$; PBS, $1 \mathrm{~min}$; followed by dehydration in graded ethanol and air drying. Sections were treated overnight with $8 \mu \mathrm{l}$ of boiled ( $2 \mathrm{~min}$ ) hybridization $\mathrm{mix}$ under siliconised coverslips in a humidified atmosphere at $42^{\circ} \mathrm{C}$, washed $2 \mathrm{~h}$ in $50 \%$ formaldehyde $/ 2 \times \mathrm{SSC} / 10 \mathrm{~mm} \quad \beta$-mercaptoethanol at $37^{\circ} \mathrm{C}$, treated with $50 \mu \mathrm{g} \mathrm{ml}^{-1}$ RNAse for $15 \mathrm{~min}$, washed again overnight, and dehydrated in graded ethanol. Slides 
were dipped in Kodak NTB-2 emulsion, autoradiographed for about 10 days at $4^{\circ} \mathrm{C}$, developed in Kodak D-19 for $3 \mathrm{~min}$, washed in $1 \%$ acetic acid for $1 \mathrm{~min}$ and fixed in $30 \%$ sodium thiosulphate for $3 \mathrm{~min}$. Sections were stained with Giemsa and visualized using a Leitz Labovert bright-field/dark-field microscope.

\section{Results}

\section{Isolation and structure of the Pax8 cDNAs}

Pax 8 was identified by sequencing $c 960$, a short cDNA isolated from an 8.5 day p.c. embryonic cDNA library (Fahrner and Hogan, 1985) using a low-stringency screen. This clone contained part of a new paired box sequence. A $112 \mathrm{bp} \mathrm{EcoRI-NciI}$ fragment of c960 (indicated as probe 1 in Fig. 1) was used to screen the above cDNA library under high-stringency conditions. A $552 \mathrm{bp}$ cDNA clone, c2A, was isolated. It contained more of the paired box as well as sequences downstream. The entire c2A sequence was found to be present in the corresponding region of the genomic clone (data not shown). To isolate full-length $\mathrm{Pax} 8$ cDNA, the above cDNA library was screened again using the whole $\mathrm{c} 2 \mathrm{~A}$ clone as a probe. Two largely overlapping cDNAs, c3B and c27B, isolated in this screen, are shown schematically in Fig. 1. Together they span 2528 bp and include the entire 1371 bp coding region of $\operatorname{Pax} 8$ (Fig. 2).

The clone $\mathrm{c} 3 \mathrm{~B}$ has an AAUAAA polyadenylation signal (Proudfoot and Brownlee, 1976; Fitzgerald and Shenk, 1981) near its $3^{\prime}$ end, followed 12 nucleotides further downstream by a stretch of 14 adenosine residues. Hence, c3B most likely represents the authentic $3^{\prime}$ end of $P a x 8$ mRNA. Because the Northern blot analysis indicates a Pax8 transcript of $3.1 \mathrm{~kb}$, approximately 600 nucleotides of the $5^{\prime}$ untranslated region are still lacking in the full length $\operatorname{Pax} 8 \mathrm{cDNA}$ sequence.

Comparison of the nucleotide sequence of the paired box of $\operatorname{Pax} 8$ with those of published paired box genes indicates that the $P a x 8$ and $P a x 2$ paired domains are very similar and constitute a separate class of paired domains (Table 1).

\section{The open reading frame of the $\mathrm{Pax} 8$ gene}

The Pax 8 cDNA clone c27B contains a large open reading frame that could translate into a protein of 457 amino acids (aa) containing the paired domain near its amino terminus (Figs 1 and 2). This open reading frame begins at nucleotide 156 and ends with a stop codon UAG at position 1527 . The sequence surrounding this first AUG codon does not match perfectly with Kozak's optimal mutation consensus (CC(A/G)CCAUGG; Kozak, 1986). However, the occurrence of stop codons in all reading frames upstream of the AUG codon at position 156 strongly indicates that this is the start of an open reading frame. Furthermore, the second AUG codon, at position 459 , occurs in the paired domain, making it an unlikely candidate for a translational start site.

The conservation of $\operatorname{Pax} 8$ paired box sequences at the amino acid level is even stronger than at the nucleotide level, suggesting a conservation of protein domain

Table 1. Nucleotide (ntd) and amino acid (aa) identities between the paired domain of Pax8 and published paired box sequences (in \%)

\begin{tabular}{lcc}
\hline Gene & ntd 1-384 & aa 1-128 \\
\hline Pax1 & 67.7 & 71.9 \\
HuP48 & 68.7 & 71.9 \\
Pox meso(P29) & 66.7 & 70.3 \\
Pox neuro(P4) & 64.3 & 71.1 \\
Pax2 & 80.2 & 89.8 \\
HuP1 & 67.2 & 71.1 \\
HuP2 & 65.9 & 71.1 \\
prd & 61.2 & 64.8 \\
gsb-p(BSH4) & 55.7 & 60.9 \\
gsb-d(BSH9) & 57.8 & 62.5
\end{tabular}

The published genes are Pax1 (Deutsch et al. 1988), Pax2 (Dressler et al. 1990), Pox neuro(P4)/Pox meso(P29) (Bopp et al. 1989), HuP48/HuP1/HuP2 (Burri et al. 1989), prd (Frigerio et al. 1986; Bopp et al. 1986) and $g s b-p$ (BSH4)/gsb-d(BSH9) (Baumgartner et al. 1989).

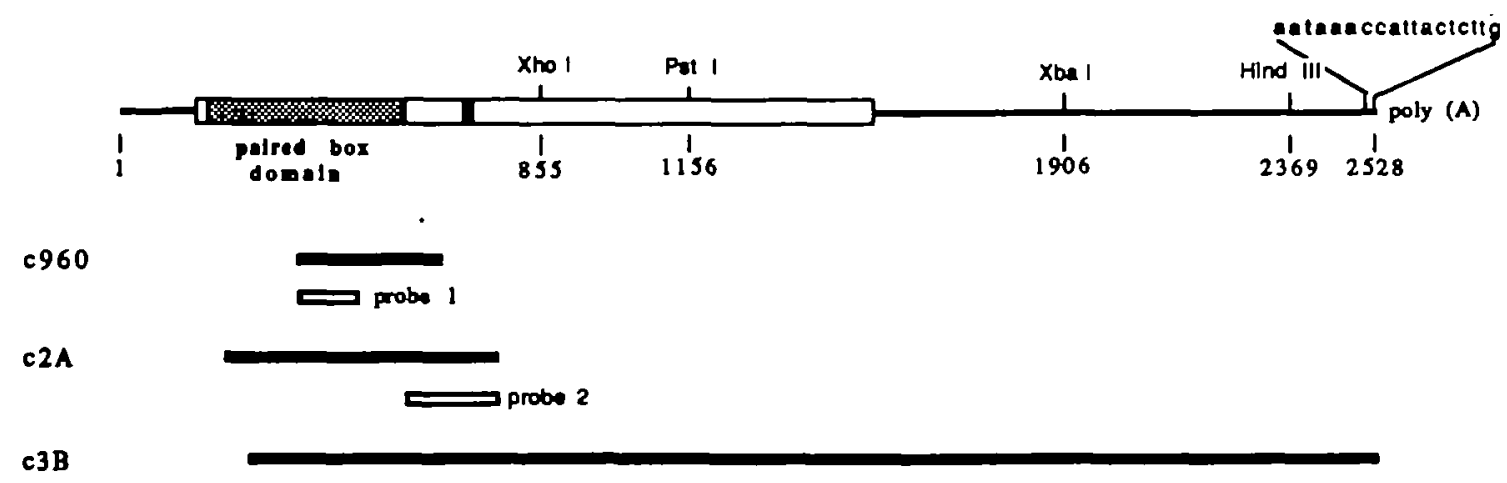

c27B

Fig. 1. The composed structure of $\operatorname{Pax} 8$ cDNA. The coding region is represented by an open box. The paired box domain and the conserved octapeptide are indicated as dotted and filled boxes, respectively. The polyadenylation site is shown with its adjacent sequences immediately preceding the poly-A tail. The Pax 8 cDNA clones and probes used for Northern analysis and in situ hybridization are outlined underneath. 
function (Table 1). Similar to Pax1 (Deutsch et al. 1988) and Pax2 (Dressler et al. 1990), Pax 8 protein contains no paired type homeodomain, a characteristic of paired and gooseberry proteins (Bopp et al. 1986). Another protein region conserved among several paired box genes, the octapeptide, was recently described by Burri et al. (1989). The octapeptide region is found 43 amino acids downstream from the paired domain in $\operatorname{Pax} 8$. The spacing between the paired domain and the octapeptide in the Pax2 protein (41aa) is very similar. The Pax8

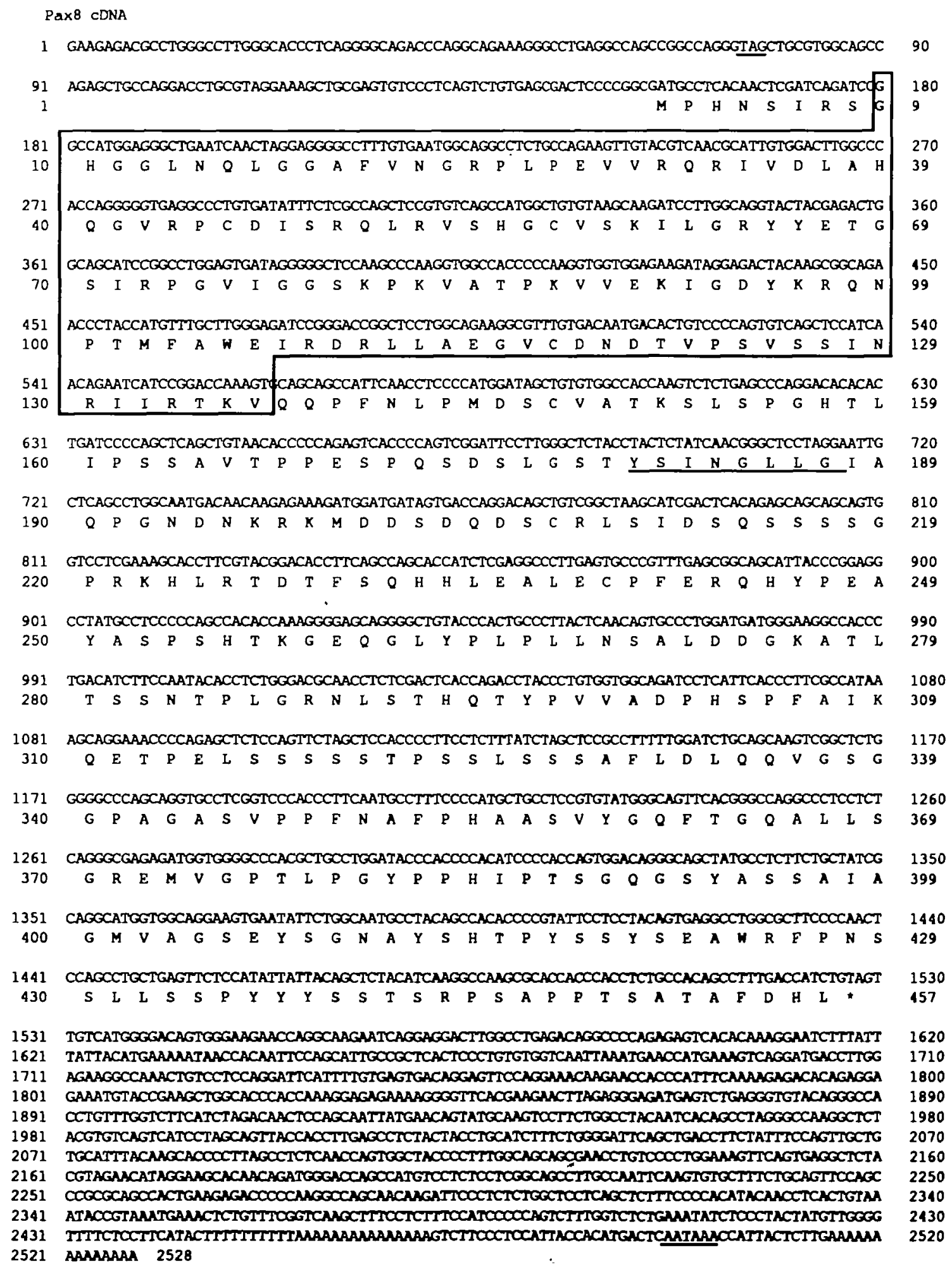

Fig. 2. Nucleotide and predicted amino acid sequences of $P a x 8$ gene. The paired domain sequences are boxed. A stop codon (TAG) preceding the putative ATG initiation site in the same frame, the octapeptide and the polyadenylation site (AATAAA) are indicated by the solid underlines. 


\begin{tabular}{|c|c|c|c|c|c|c|c|c|}
\hline Hup1 & $\mathrm{His}$ & Ser & Ile & Asp & Gly & Ile & Leu & GlJ \\
\hline Hup & - & - & - & - & - & - & - & $\mathrm{Se}$ \\
\hline$g s b-d$ (BSH9) & - & - & - & - & - & - & - & \\
\hline$g s b-p$ (BS & Tyr & Thr & - & Asn & - & - & - & \\
\hline Pax & Tyx & - & - & Asn & - & - & - & \\
\hline Pax 8 & Tyr & - & - & Asn & - & Leu & - & - \\
\hline & & & & & $1 y$ & 1 & eu & \\
\hline
\end{tabular}

Flg. 3. Compilation of homologous octapeptide sequences found in $\operatorname{Pax} 8$ and several other published paired box containing genes. The genes HuP1 and HuP2 are from man (Burri et al. 1989), gsb-p and gsb-d are from Drosophila (Baumgartner et al. 1987). Pax2 is from mouse (Dressler et al. 1990). The consensus sequence is as proposed by Burri et al. (1989).

octapeptide differs from that of $P a x 2$ by only one conservative amino acid substitution (Fig. 3). Pax8 protein has a repeat of leucine residues at aa positions $265,272,279$ and 286. However, occurrence of two proline residues within this repeat makes it unlikely that this repeat forms the $\alpha$-helix, needed for a 'leucine zipper' configuration (Landschulz et al. 1988).

\section{The chromosomal localization of the Pax8 gene}

To determine the chromosomal location of $P a x 8$, we have used the mouse interspecies backcrosses (Guenet, 1986). Using an approx. 700 bp genomic HindIII-NcoI fragment from the $\operatorname{Pax} 8$ locus as a probe, we have demonstrated a Sau3A restriction fragment length polymorphism (RFLP) between C57BL/ 6 mice and an inbred Mus spretus line SPE/Pas (data not shown). This RFLP was used to probe DNAs from a panel of backcross progeny of (C57BL/6 $\times$ SPE/Pas) $F_{1}$ females $\times$ C57BL $/ 6$ males. The segregation pattern of $\operatorname{Pax} 8$ alleles was compared to the segregation patterns of all other genes analyzed in the same panel of backcrosses. Pax 8 is closely linked to the surfeit (surf) $(0 / 30$ recombinants scored) and HOX-5 (4/28 recombinants scored, linkage distance is approx. $14 \mathrm{cM}$ organs) gene clusters within the proximal portion of chromosome 2 (Stubbs et al. 1990).

\section{Expression pattern of Pax 8 RNA in the mouse embryo and adult tissues}

To determine the tissue specificity, temporal and spatial expression pattern of Pax8 RNA, we used Northern blot and in situ hybridization analyses. Two different cDNA fragments of $P a x 8$ were used as probes; the 112 bp EcoRI-NciI fragment from clone 960 containing the paired box sequences and the $\operatorname{Pax} 8$ specific 184 bp NcoI-Eco RI fragment from clone c2A (Probe 1 and 2, respectively; Fig. 1). Both probes revealed the same pattern of Pax 8 expression. Only results obtained with probe 2 are presented here.

Northern blot analysis of poly(A) ${ }^{+}$RNA samples from various adult tissues revealed a $3.1 \mathrm{~kb} P a x 8$ message in kidney (Fig. 4). No $\operatorname{Pax} 8$ transcripts were detected in brain, liver, lung, spleen, muscles, ovary, pancreas or testis. Furthermore, no Pax 8 transcripts could be detected on the Northern blots of poly $(A)^{+}$

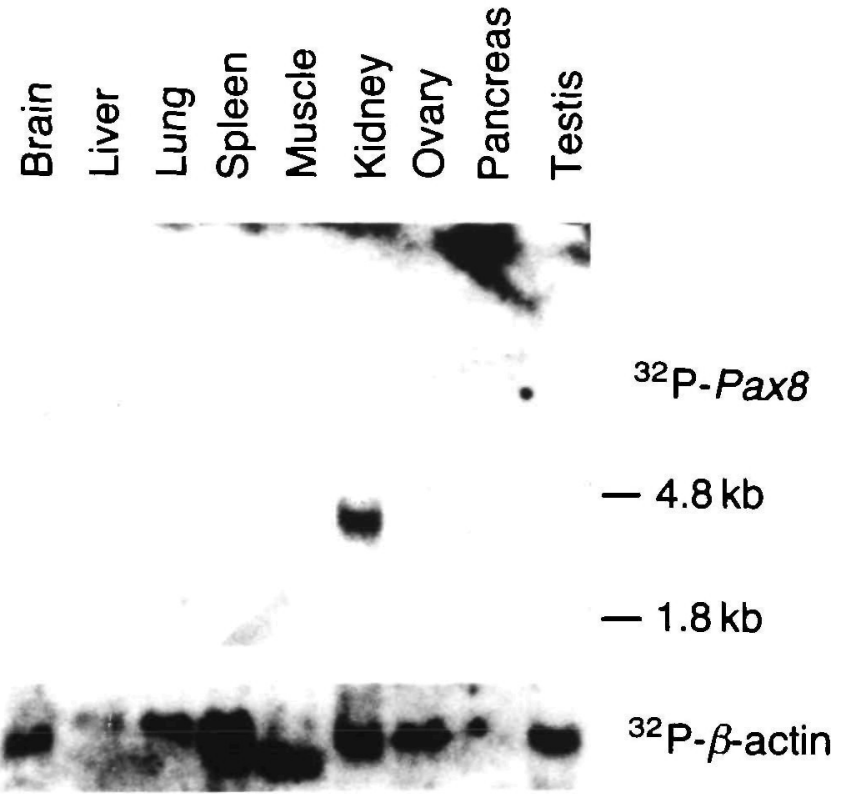

Fig. 4. Northern blot analysis of $\operatorname{Pax} 8$ transcripts in the adult tissues of the mouse. Approximately $5 \mu \mathrm{g}$ of polyadenylated RNA from corresponding tissues were hybridized with a unique $\operatorname{Pax} 8$ probe depicted in Fig. 1 as probe 2 . The presence and integrity of RNA on the blots was confirmed by the hybridization with a $\beta$-actin probe.

RNAs from 10 to 17 day p.c. embryos, even after prolonged exposure (data not shown). However, Pax8 mRNA may be scarce in samples of whole embryo poly $(\mathrm{A})^{+}$RNA because its expression is restricted to small regions of the embryo and the level of this expression is low.

To precisely localize the spatial and temporal distribution of $P a x 8$ RNA, in situ hybridization analysis of tissue sections from mouse embryos of various developmental stages was done. Sections were hybridized to the ${ }^{35}$ S-UTP/CTP-labeled antisense RNA probes (material and methods). Sense RNA probes were used as negative controls.

Fig. 5 illustrates the expression of $P a x 8$ in the developing excretory system. Because $\mathrm{Pa} 2$ gene is also expressed in this system (Dressler et al. 1990), the patterns of expression of both genes were compared using parallel sections. The $527 \mathrm{bp} B a m \mathrm{HI}-E c o$ RI fragment unique for the Pax2 gene (Dressler et al. 1990) was used to produce RNA probes. Both $\operatorname{Pax} 2$ and $P a x 8$ are expressed in the nephrogenic cord and in the more anterior mesonephric tubules of 10.5 day p.c. embryo (Fig. 5A-D). The mesonephric tubules are induced in the nephrogenic cord mesenchyme by the nephric (Wolffian) duct during its growth in the posterior direction. Only Pax2 was detected in the nephric duct (Fig. 5C,D).

During the next stage of kidney development, the ureteric bud emerges from the most caudal portion of the nephric duct, invades the metanephrogenic mesenchyme and branches. These branches induce the mesenchymal cellular condensations (Saxén, 1987). 
Only Pax2 transcripts are detected in the branching ureter at 13.5 days gestation, whereas both $P a x 2$ and Pax 8 are expressed in the mesenchymal condensations and in the epithelial structures forming from the condensations (Fig. 5E-H). Thus, the inducing part of the secretory system, the nephric duct and the ureter, has no detectable Pax 8 expression, whereas the responding part, the mesenchymal condensations and ultimately the S-shaped bodies, express Pax8. This is demonstrated more clearly in Fig. $5 \mathrm{M}, \mathrm{N}$; only the mesenchymal cells that have condensed around the ureteric duct express $\operatorname{Pax} 8$. The ureteric duct itself and the non-condensed mesenchymal cells show no Pax 8 expression.

At day 16.5 of gestation morphogenesis proceeds in the cortex of the metanephros where $\operatorname{Pax} 8$ and $\operatorname{Pax} 2$ are expressed strongly (Fig. 5I-L). At this stage of gestation, Pax2 transcripts are also detected in the pancreas (Fig. 5K,L).

Fig. 6 shows the expression of $\operatorname{Pax} 8$ in the developing thyroid gland. Pax2 expression was not detected in this organ at any stage in development (data not shown). Pax 8 transcripts first appear in the area of thyroid evagination from the floor of the pharynx at day 10.5 p.c. (Fig. 6A,B) and remain visible as the thyroid vesicle buds off from the floor of the pharynx and migrates caudally (Fig. 6C-H). Eventually, a twolobed gland is formed. At this stage Pax 8 is expressed in the lobes (Fig. 6I,J) and in the isthmus, which connects the lobes (Fig. 6K,L). No Pax 8 expression is seen in the parathyroid gland, which develops independently from two pairs of pharyngeal pouches and subsequently embeds itself in the thyroid tissue (Fig. 6I,J).

$\operatorname{Pax} 8$ is expressed transiently in the myelencephalon (Fig. 7I,J) and through the entire length of the neural tube at day 11.5 of gestation (Fig. 7A, B,E,F). The expression subsides at day 12.5 and is not detectable at day 13.5 of gestation (data not shown). The pattern of Pax 8 expression in the neural tube is very similar, if not identical, to that of Pax2 at this stage of development (Fig. 7C,D,G,H). However, the genes differ in their temporal expression patterns in the CNS, because $\mathrm{Pax} 2$ expression in the spinal column continues at least to day 18.5 of gestation (Nornes et al. 1990).

\section{Discussion}

In this report, we have described a novel murine paired box gene, Pax8, which is expressed in a tissue-specific manner during development. The 2528 bp $\operatorname{Pax} 8$ cDNA sequence encompasses the entire coding region for a 457 aa protein. A paired domain is located near the amino terminus of this conceptual protein. Interestingly, all the paired box genes described so far in man, mouse and fly contain the paired domain near the amino end of their corresponding proteins. A conservation of this domain among such different species suggests conservation of function. However, this function is at present unknown. It has been shown that the products of the Drosophila segmentation gene paired, which contain both paired and homeodomains, can bind specific DNA sequences (Hoey and Levine, 1988; Treisman et al. 1989). Not all of these DNAbinding activities can be ascribed to the homeodomain of the paired protein (Treisman et al. 1989). Thus, the DNA-binding function of the paired domain remains an attractive hypothesis.

In Drosophila, two paired box genes that do not contain a homeodomain have been described (Bopp et al. 1989). Pax8 and two other murine genes, Paxl (Deutsch et al. 1988) and Pax2 (Dressler et al. 1990), share this characteristic. Furthermore, the paired domains of $\operatorname{Pax} 8$ and $\operatorname{Pax} 2$ have a pronounced similarity. This structural similarity is especially noteworthy because both genes have similar tissue-specific expression. Using in situ hybridization, we have compared the expression of $\operatorname{Pax} 8$ and $\operatorname{Pax} 2$ in the developing excretory system. The cellular compartments of this system result from the reciprocal inductive interactions between the growing nephric duct and later ureter, and nephrogenic mesenchyme (for review see Saxén, 1987). The nephrogenic mesenchyme responds to the induction by formation of cellular condensations, which give rise to the epithelial structures of the nephrons. The expression of both genes has parallels with the morphogenetic changes during these inductive processes: whereas Pax 8 expression is restricted to the responding tissues, $P a x 2$ transcripts can be detected both in the inducing and in the responding tissues of the kidney.

During the first stage of kidney development, the nephric duct induces the formation of the mesonephric tubules where both $P a x 8$ and $P a x 2$ are expressed. The tubules are organized segmentally along the rostrocaudal axis. However, this segmental pattern does not correspond to the primary segmentation of the mouse embryo into somites. Thus, it is questionable whether $\operatorname{Pax} 8$ or $\operatorname{Pax} 2$ play the part in primary segmentation analogous to their Drosophila homologs. Accordingly, we could not detect $P a x 8$ or Pax2 expression by in situ hybridization at 8.5 day of gestation when segment determination is occurring (Hogan et al. 1985; Hogan et al. 1986).

The molecular mechanisms of signal transduction underlying the inductive process of epithelium forma-

Fig. 5. Comparison of expression of $\operatorname{Pax} 8$ and $\operatorname{Pax} 2$ genes in the developing meso- and metanephros. Parasagittal section through 10.5 day p.c. embryo, magnification $\times 40$ (A,B,C,D). MD, mesonephric duct; MT, mesonephric tubules; NC, nephrogenic cord; S, somite. Expression of $\operatorname{Pax} 8(\mathrm{~A}, \mathrm{~B})$ and $\operatorname{Pax} 2$ (C,D). Note the absence of $\operatorname{Pax} 8$ expression in the mesonephric duct. Parasagittal section of 13.5 day p.c. embryo, magnification $\times 100(\mathrm{E}, \mathrm{F}, \mathrm{G}, \mathrm{H})$. UD, ureteric duct; $\mathrm{MC}$, mesenchymal condensation; $\mathrm{SB}$, S-shaped body. Expression of $\operatorname{Pax} 8(\mathrm{E}, \mathrm{F})$ and $\operatorname{Pax} 2(\mathrm{G}, \mathrm{H})$. Note the absence of Pax 8 expression in the ureter. Parasagittal section of 16.5 day p.c. embryo, magnification $\times 40(\mathrm{I}, \mathrm{J}, \mathrm{K}, \mathrm{L})$. P, pancreas. Expression of $\operatorname{Pax} 8(\mathrm{I}, \mathrm{J})$ and $\operatorname{Pax} 2(\mathrm{~K}, \mathrm{~L})$. Note the absence of Pax8 expression in the medulla of the kidney. Parasagittal section of 13.5 day p.c. embryo, expression of $\operatorname{Pax} 8(\mathrm{M}, \mathrm{N})$, magnification $\times 100$. 

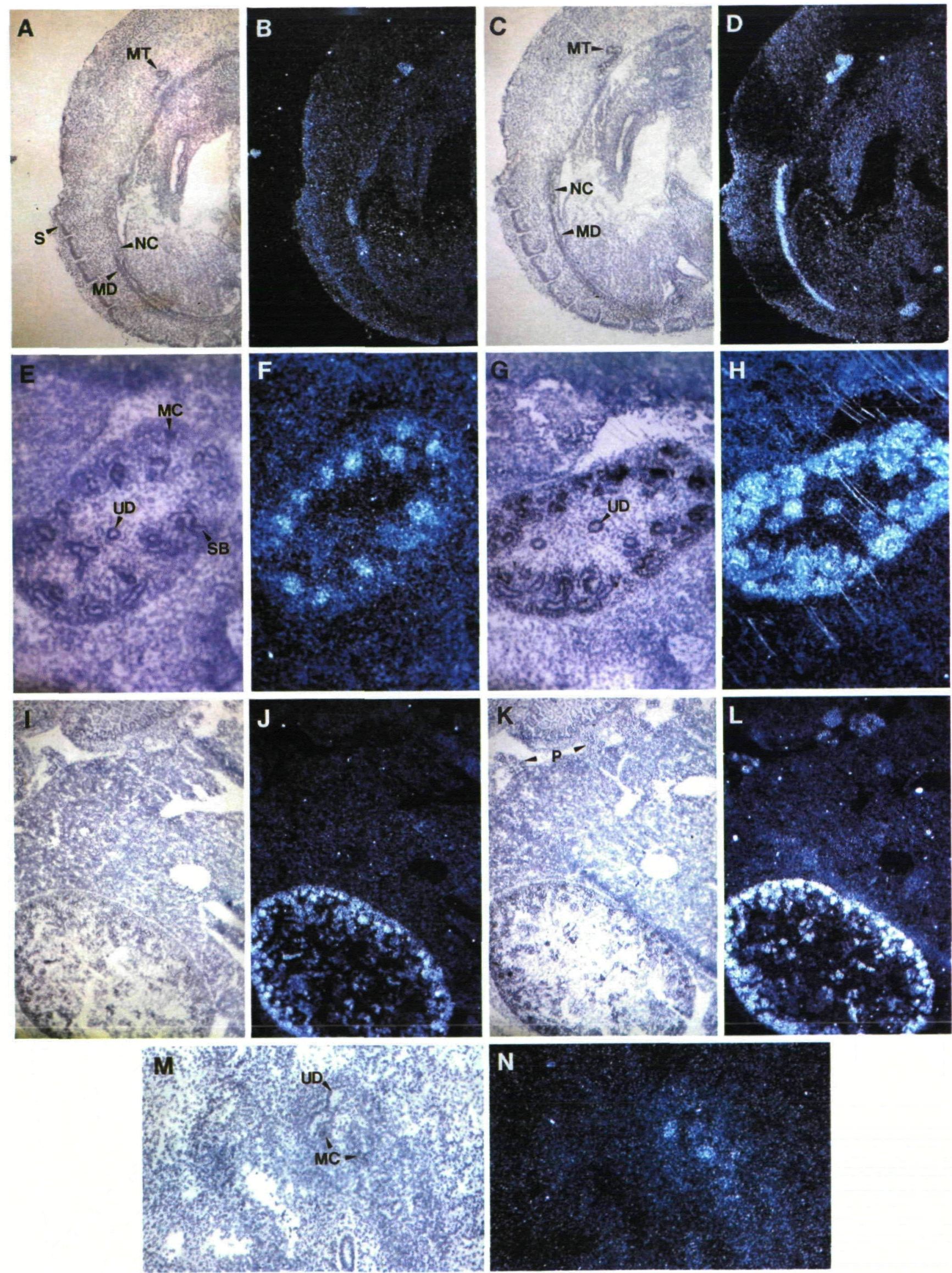

N

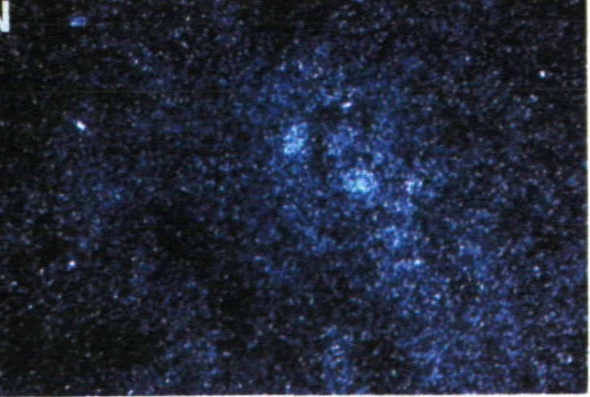




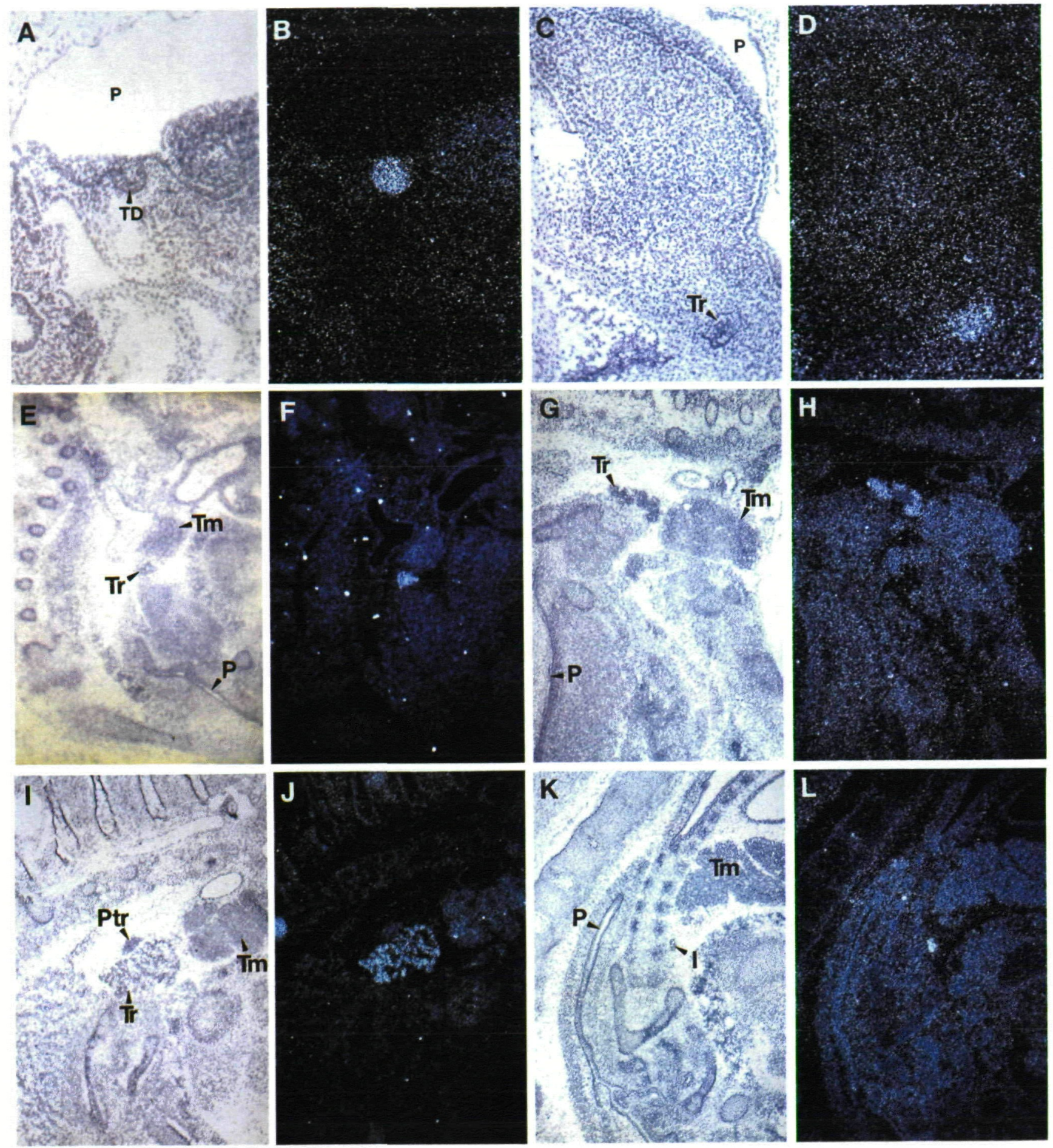

Fig. 6. Expression of $P a x 8$ in the developing thyroid gland. Sagittal section of 10.5 day p.c. embryo, magnification $\times 100$ (A,B). TD, thyroid diverticulum; P, pharinx. Sagittal section of 11.5 day p.c., $\times 100$ (C,D), 13.5 day p.c., $\times 40$ (E,F) and 14.5 day p.c., $\times 40(\mathrm{G}, \mathrm{H})$ embryo. Parasagittal section $(\mathrm{I}, \mathrm{J})$ and sagittal section $(\mathrm{K}, \mathrm{L})$ of 16.5 day p.c. embryo, magnification $\times 40$. Tr, thyroid; Ptr, parathyroid; I, isthmus; Tm, thymus. 


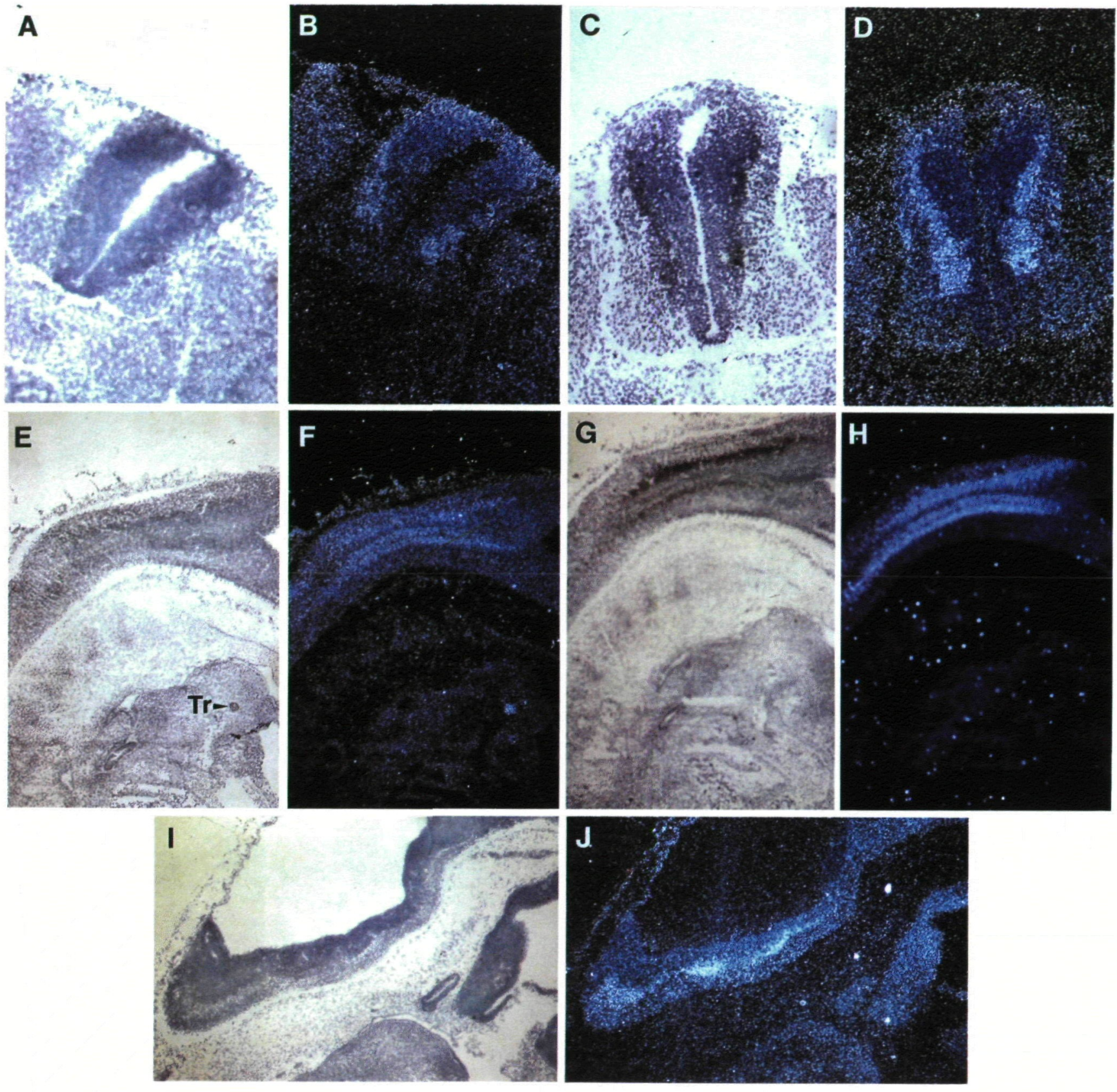

Fig. 7. Expression of $\operatorname{Pax} 8$ and $\operatorname{Pax} 2$ in the CNS of 11.5 day p.c. embryo. Cross sections, magnification $\times 100$ (A-D). Sagittal sections, magnification $\times 40(\mathrm{E}-\mathrm{H})$. Expression of Pax8 $(\mathrm{A}, \mathrm{B}, \mathrm{E}, \mathrm{F})$ and $\operatorname{Pax} 2(\mathrm{C}, \mathrm{D}, \mathrm{G}, \mathrm{H})$. Tr, thyroid. Parasagittal section through the myelencephalon, expression of $\operatorname{Pax} 8(\mathrm{I}, \mathrm{J})$, magnification $\times 40$. 
tion in the metanephric kidney are not known. Two levels of determination can be distinguished in this process. First, the metanephrogenic mesenchyme isolated from an 11 day embryo is already predetermined to respond to the inducing agents by tubule formation (Grobstein, 1955; Saxén, 1970). It may imply that the cells of the metanephric blastema have already reached a state in which only few additional factors are needed to start morphogenesis. Hypothetically, transcription factors, $P a x 8$ and $P a x 2$ among them, that are induced in these cells during . this period could play a crucial role in this process: Not only ureter but also neural tube can induce epithelialization of the mesenchymal cells (Grobstein, 1955). Interestingly, $\operatorname{Pax} 2$ is expressed in both" these tissues. The second level, an actual determination of the mesenchymal cells to become the components of nephron is achieved only after approximately $24 \mathrm{~h}$ of contact with the inducter (Saxén and Lehtonen, 1978). The molecular events that take place during this time are completely obscure. Subsequently, irreversible morphogenetic changes occur including the formation of the basal membrane, establishment of the epithelial polarity and an increase in cellular adhesivity (Saxén, 1987).

Profound molecular changes in the extracellular matrix and cell surface molecules during the nephron formation have also been reported recently. The expression of fibronectin and interstitial type I and type III collagens is replaced by the basement membrane components including type IV collagen and laminin chains (Ekblom, 1981; Ekblom et al. 1981b; Ekblom et al. 1980; Senior et al. 1988; Laurie et al. 1989; Ekblom et al. 1990). Antibodies against laminin A chain can inhibit the polarization of the mesenchymal cells, suggesting a functional role for laminin in this process (Klein et al. 1988b). Another extracellular matrix glycoprotein, tenascin, is induced around the mesenchymal condensations (Aufderheide et al. 1987). Furthermore, neural cell adhesion molecules (N-CAM) are replaced by uvomorulin, another primary CAM (Vestweber et al. 1985; Klein et al. 1988a). Another result of induction is that the mesenchymal cells acquire the responsiveness to transferrin (Ekblom et al. 1983) and express the desmosomal proteins (Garrod and Fleming, 1990). Being putative transcription factors, Pax8 and Pax2 may be involved in the described molecular processes.

It is also worth noting that the developing nephron itself becomes segregated into three segments, i.e. glomerulus, proximal and distal tubules. The markers specific for each of these segments have been described (Ekblom et al. 1981a). Pax8 and Pax2 are molecular markers characteristic of both early mesenchymal condensations and late epithelial structures resulting from condensations.

Using an interspecies backcross, we have mapped Pax 8 to the centromeric region of mouse chromosome 2 in a close linkage to the surf locus. It would be interesting to determine whether the human homolog of $P a x 8$ is located on human chromosome $9 q$ which reveals a strong synteny to proximal mouse chromo- some 2 (Yon et al. 1989; Stubbs et al. 1990). Several mouse developmental mutations including Danforth's short tail $(S d)$, stubby $(s t b)$, fidget $(f i)$, lethargic $(l h)$ and rachiterata $(r h)$ are linked in the proximal portion of mouse chromosome 2 (Davisson et al. 1988). The semidominant $S d$ mutation is especially interesting in context of the present report. Recently, the surf cluster has been positioned within close proximity of the $S d$ locus (Stubbs et al. 1990). Thus, Pax8, surf and $S d$ map close to each other. The $S d$ mutation is characterized by the abnormalities of the axial skeleton and the reduction or absence of kidneys (Dunn et al. 1940). The phenotype of the skeleton and kidneys may both have a common origin from the abnormality of the notochord in the $S d$ mice (Grüneberg, 1958). However, the organ culture studies have revealed a reduction of the tubule formation intrinsic to the mutant metanephrogenic mesenchyme (Gluecksohn-Waelsch and Rota, 1963). Because Pax8 is expressed in the developing tubules, it would be interesting to investigate its association with the $S d$ mutation.

The expression of Pax8 in the developing neural tube, secretory system and thyroid gland, which originate from ectoderm, mesoderm and endoderm, respectively, may indicate pleiotropic functions of the Pax8 gene. Furthermore, we cannot exclude the possibility that $\operatorname{Pax} 8$ is also expressed in the mesenchymal component of the developing thyroid. Both in the mesenchymal condensations of the kidney and in the developing thyroid gland, $\operatorname{Pax} 8$ expression is associated with the zones of changes in cell proliferation (Saxén et al. 1983; Smuts et al. 1978). Common functions of $\mathrm{Pax} 8$ in the developing kidney and thyroid associated with the appearance and/or maintenance of the cell polarization also cannot be ruled out (Chambard et al. 1981).

Because of the overlapping expression pattern of $P a x 8$ and $P a x 2$, it would be interesting to find out whether these two gene products interact with each other at the molecular level.

We thank K. Fahrner and B. Hogan for the cDNA library. We thank U. Deutsch for the initial screening of this library and $\mathbf{R}$. Balling for the Sau3A blot. We are also grateful to $\mathbf{R}$. Altschaffel for the excellent photographic work. The valuable suggestions of M. Gross, M. Kessel and G. I. Kristjansson on the manuscript are thankfully acknowledged. Continuous thanks go also to M. Wesselhoft, C. Lobe and A. Stoykova. This work was supported by the Max-Planck-Society. D. Plachov was supported by the DECHEMA fellowship.

\section{References}

AKAM, M. (1987). The molecular basis for metameric pattern in the Drosophila embryo. Development 101, 1-22.

Aufderheide, E., Chiquet-Ehrismann, R. and Ekblom, P. (1987). Epithelial-mesenchymal interactions in the developing kidney lead to expression of tenascin in the mesenchyme. $J$. Cell Biol. 105, 599-608.

Balling, R., Deutsch, U. ANd Gruss, P. (1988). Undulated, a mutation affecting the development of the mouse skeleton, has a point mutation in the paired box of Pax 1. Cell 55, 531-535.

Balmgartner, S., Bopp, D., Burri, M. and Noll, M. (1987). Structure of two genes at the gooseberry locus related to the 
paired gene and their spatial expression during Drosophila embryogenesis. Genes Dev. 1, 1247-1267.

Bopp, D., Burri, M., Baumgartner, S., Frigerio, G. and Noli, M. (1986). Conservation of a large protein domain in the segmentation gene paired and in functionally related genes of Drosophila. Cell 47, 1033-1040.

Bopp, D., Jamet, E., Baumgartner, S., Burr, M. AND Noll, M. (1989). Isolation of two tissue-specific Drosophila paired box genes, Pox meso and Pox neuro. EMBO J. 8, 3447-3457.

Burri, M., Tromvoukis, Y., Bopp, D., Frigerio, G. and Noll, M. (1989). Conservation of the paired domain in metazoans and its structure in three isolated human genes. $E M B O \mathrm{~J} .8$, $1183-1190$.

Chambard, M., Gabrion, J. and Mauchamp, J. (1981). Influence of collagen gel on the orientation of epithelial cell polarity: follicle formation from isolated thyroid cells and from preformed monolayers. J. Cell Biol. 91, 157-166.

Chirgwin, J. M., Przybyla, A. E., MacDonald, R. J. and RUTTER, W. J. (1979). Isolation of biologically active ribonucleic acid from sources enriched in ribonucleases. Biochemistry 18, 5294-5299.

Côté, S., Preiss, A., Haller, J., Schuh R., Kienlin, A., SEIFERT, E. AND JÄCKLE, H. (1987). The gooseberry-zipper region of Drosophila: five genes encode different spatially restricted transcripts in the embryo. EMBO J. 6, 2793-2801.

Davisson, M. T., Roderick, T. H., Hillyard, A. L. AND Dooutrle, D. P. (1988). The linkage map of the mouse. Mouse News Lett. 81, 12-19.

Deutsch, U., Dressler, G. R. And Gruss, P. (1988). Pax 1, a member of a paired box homologous murine gene family, is expressed in segmented structures during development. Cell 53, $617-625$.

Dressler, G. R., Deutsch, U., Balling, R., Smon, D., Guenet, J.-L. AND Gruss, P. (1988). Murine genes with homology to Drosophila segmentation genes. Development 104 Supplement 181-186.

Dressler, G. R., Deutsch, U., Chowdhury, K., Nornes, H. O. AND Gruss, P. (1990). Pax2, a new murine paired-boxcontaining gene and its expression in the developing excretory system. Development (in press).

Dunn, L. C., Gluecrsohn-Schoenheimer, S. ANd Bryson, V. (1940). A new mutation in the mouse affecting spinal column and urogenital system. J. Hered. 31, 343-348.

Ekblom, M., Klenn, G., Mugrauer, G., Fecker, L., Deutzman, R., TIMPL, R. AND EKBLOM, P. (1990). Transient and locally restricted expression of laminin A chain mRNA by developing epithelial cells during kidney organogenesis. Cell 60, 337-346.

EквLOM, P. (1981). Formation of basement membranes in the embryonic kidney: an immunohistological study. J. Cell Biol. 91 , $1-10$.

Ekblom, P., Alttalo, K., Vahery, A., Timpl, R. and Saxén, L. (1980). Induction of a basement membrane glycoprotein in embryonic kidney: possible role of laminin in morphogenesis. Proc. natn. Acad. Sci. USA 77, 485-489.

Ekblom, P., Lehtonen, E., Saxén, L. and Timpl, R. (1981b). Shift in collagen type as an early response to induction of the metanephric mesenchyme. J. Cell Biol. 89, 276-283.

Ekblom, P., Miettinen, A., Virtanen, I., Wahlstrom, T., DAWNAY, A. AND SAXÉN, L. (1981a). In vitro segregation of the metanephric nephron. Devl Biol. 84, 88-95.

Ekblom, P., Thesleff, I., Saxén, L., Miettinen, A. and Timpl, R. (1983). Transferrin as a fetal growth factor: Acquisition of responsiveness related to embryonic induction. Proc. natn. Acad. Sci. USA 80, 2651-2655.

Fahrner, K., Hogan, B. L. M. and Flavell, R. A. (1987). Transcription of $\mathrm{H}-2$ and $\mathrm{Qa}$ genes in embryonic and adult mice. EMBO J. 6, 1269-1271.

Feingerg, A. P. ANd Vogelstein, B. (1983). A technique for radiolabeling DNA restriction endonuclease fragments to high specific activity. Anal. Biochem. 132, 6-13.

Fitzgerald, M. and Schenk, T. (1981). The sequence of 5'AAUAAA-3' forms part of the recognition site for polyadenylation of late SV40 mRNAs. Cell 24, 251-260.

Frigerio, G., Burri, M., Bopp, D., Baumgartner, S. and Noll,
M. (1986). Structure of the segmentation gene paired and the Drosophila PRD gene set as part of a gene network. Cell 47, 735-746.

Garrod, D. R. AND Fleming, S. (1990). Early expression of desmosomal components during kidney tubule morphogenesis in human and murine embryos. Development 108, 313-321.

Gluecrsohn-Waelsch, S. and Rota, T. R. (1962). Development in organ tissue culture of kidney rudiments from mutant mouse embryos. Devl Biol. 7, 432-444.

GrUNEBERG, H. (1958). Genetical studies on the skeleton of the mouse. XXII. The development of Danforth's short tail. $J$. Embryol. exp. Morphol. 6, 124-148.

GrobsteIN, C. (1955). Inductive interaction in the development of the mouse metanephros. J. Exp. Zool. 130, 319-340.

GUENET, J.-L. (1986). The gene contribution of wild derived mouse inbred strains. Gene Mapping Methodology. In Topics in Microbiology and Immunology, vol. 127 (ed. M. Potter, J. Nadeau and M. P. Cancro), pp. 109-130. Springer Verlag.

HoEY, T. AND Levine, M. (1988). Divergent homeo box proteins recognize similar DNA sequences in Drosophila. Nature 332, 858-861.

Hogan, B., Constantini, F. and Lacy, E. (1986). Manipulating the Mouse Embryo: A Laboratory Manual, Cold Spring Harbor, NY, pp. 228-235.

Hogan, B., Holland, P. and Schofield, P. (1985). How is the mouse segmented? Trends Genet., March, 67-74.

Holland, P. W. H. and Hogan, B. L. M. (1988). Expression of homeo box genes during mouse development: a review. Genes Dev. 2, 773-782.

InGHAm, P. W. (1988). The molecular genetics of embryonic pattern formation in Drosophila. Nature 335, 25-34.

KilchHerr, F., Baumgartner, S., Bopp, D., Frei, E. and Noll, M. (1986). Isolation of the paired gene of Drosophila and its spatial expression during early embryogenesis. Nature $\mathbf{3 2 1}$ 493-499.

Klein, G., Langegger, M., Goridis, C. And Ekblom, P. (1988a). Neural cell adhesion molecules during embryonic induction and development of the kidney. Development 102, 749-761.

Klein, G., Langegger, M., Timpl, R. and Ekblom, P. (1988b). Role of laminin A chain in the development of epithelial cell polarity. Cell 55, 331-341.

KozAK, M. (1986). Point mutations define a sequence flanking AUG initiator codons that modulates translation by eukaryotic ribosomes. Cell 44, 283-292.

Landschulz, W. H., Johnson, P. F. and McKnight, S. L. (1988). The leucine zipper: a hypothetical structure common to a new class of DNA binding proteins. Science 240, 1759-1764.

laurie, G. W., Horikoshi, S., Killen, P. D., Segui-Real, B. AND YAMADA, Y. (1989). In situ hybridization reveals temporal and spatial changes in cellular expression of mRNA for a laminin receptor, laminin, and basement membrane (type IV) collagen in the developing kidney. J. Cell Biol. 109, 1351-1362.

LewTs, E. B. (1978). A gene complex controlling segmentation in Drosophila. Nature 276, 565-570.

MCGINNIS, W., Garber, R. L., Wirz, J., KurorWA, A. AND GEHRING, W. J. (1984). A homologous protein-coding sequence in Drosophila homeotic genes and its conservation in other metazoans. Cell 37, 403-408.

Nornes, H. O., Dressler, G. R., Knapik, E. W., Deutsch, U. AND GruSs, P. (1990). Spatially and temporally restricted expression of $\operatorname{Pax} 2$ during murine neurogenesis. Development (in press).

NÜsslein.Volhard, C. and Wieschaus, E. (1980). Mutations affecting segment number and polarity in Drosophila. Nature 287, 795-801.

PotTer, E. L. (1972). Normal and abnormal development of the kidney. Chicago: Year Book Medical Publishers.

Proudfoot, N. J. AND Brownlee, G. G. (1976). The 3' noncoding region sequences in eukaryotic messenger RNA. Nature 263, 211-214.

Sanger, F., Nicklen, S. And Coulson, A. R. (1977). DNA sequencing with chain termination inhibitors, Proc. Natl. Acad. Sci. USA 74, 5463-5467. 
SAXEN, L. (1970). Failure to demonstrate tubule induction in a heterologous mesenchyme. Devl Biol. 23, 511-523.

SaXÉn, L. (1987). Organogenesis of the Kidney. Cambridge: Cambridge University Press.

SAXÉN, L. AND Lehtonen, E. (1978). Transfilter induction of kidney tubules as a function of the extent and duration of intercellular contacts. J. Embryol. Exp. Morphol. 47, 97-109.

Saxén, L., Salonen, J., Ekblom, P. and Nordling, S. (1983). DNA synthesis and cell generation cycle during determination and differentiation of the metanephric mesenchyme. Devl Biol. 98, 130-138.

Scott, M. P. and Carroll, S. B. (1987). The segmentation and homeotic gene network in early Drosophila development. Cell 51, 689-698.

Senior, P. V., Critchley, D. R., Beck, F., Walker, R. A. and VARLEY, J. M. (1988). The localization of laminin mRNA and protein in the postimplantation embryo and placenta of the mouse: an in situ hybridization and immunocytochemical study. Development 104, 431-446.

Smuts, M. S., Hilfer, S. R. and Searls, R. L. (1978). Patterns of cellular proliferation during thyroid organogenesis. J. Embryol. Exp. Morphol. 48, 269-286.

Stubes, L., Huxley, C., Hogan, B., Evans, T., Fried, M. Duroule, D. And Lehrach, H. (1990). The HOX-5 and surfeit gene clusters are linked in the proximal portion of mouse chromosome 2. Genomics 6, 645-650.

Treisman, J., Gönczy, P., Vashishtha, P., Harris, M. and DEsplan, C. (1989). A single amino acid can determine the DNA binding specificity of homeodomain proteins. Cell $\mathbf{5 9}$, 553-562.

Vestweber, D., Kemler, R. ANd Ekblom, P. (1985). Celladhesion molecule uvomorulin during kidney development. Devl Biol. 112, 213-221.

Yon, J., Palmer, R. W., Sheer, D. and Fried, M. (1989). Localization of the Surfeit gene cluster containing the ribosomal protein gene S7a to chromosome bands 9q. Ann. Hum. Genet. 53, $149-155$ 